\title{
Solid-phase microextraction and gas chromatography-mass spectrometry for quantitative determination of chlordecone in water, plant and soil samples
}

\author{
Alain SOLER $^{1 *}$, Marc LeBRUN ${ }^{2}$, Yoan LABROUSSE ${ }^{3}$, Thierry WOIGNIER ${ }^{4}$
}

\author{
${ }^{1}$ Cent. Coop. Int. Rech. Agron. \\ Dév. (CIRAD), Persyst, UR \\ Banan. Plantain and Pineapple \\ Crop. Syst., CAEC, BP 214, \\ 97285 Le Lamentin cedex 2 , \\ Martin., Fr. \\ alain.soler@cirad.fr \\ 2 Cirad, Persyst, UMR \\ Qualisud, 34398 Montp., Fr., \\ m.lebrun@cirad.fr \\ ${ }^{3}$ IRD, Ins. Méditerr. Biodivers. \\ Ecol. Mar. Cont. (IMBE), \\ Aix-Marseille Univ., \\ UMR CNRS IRD Avignon \\ Univ., CAEC, BP 214 \\ 97285 Le Lamentin cedex 2 , \\ Martin., Fr., \\ yoan.labrousse@ird.fr \\ 4 IMBE, Aix-Marseille Univ., \\ UMR CNRS 7263 IRD \\ 237 Avignon Univ., \\ F-13397 Marseille, Fr., \\ thierry.woignier@imbe.fr
}

${ }^{*}$ Correspondence and reprints

Received 23 September 2013 Accepted 14 January 2014

Fruits, 2014, vol. 69, p. 325-339 (C) 2014 Cirad/EDP Sciences All rights reserved

DOI: 10.1051/fruits/2014021

www.fruits-journal.org

RESUMEN ESPAÑOL, p. 339
Solid-phase microextraction and gas chromatography-mass spectrometry for quantitative determination of chlordecone in water, plant and soil samples.

Abstract - Introduction. Chlordecone (CLD), an organochlorine formerly used to control the banana black weevil, is strongly adsorbed on soils, particularly on andosols. A simplified analytical procedure for the quantitative determination of chlordecone residues in water and micro-samples of soil and plants was compared with a standard method. Materials and methods. The procedure combines a simplified sampling protocol and a 10-min solid phase microextraction (SPME), followed by gas chromatographic separation (GC) and mass spectrometric (MS and MS/MS) identification. Quantitation of CLD used a standard addition method with zero extrapolation. First, seventy samples were analysed using the proposed method and the standard method based on hot solvent extraction. Second, fifteen soil samples were analysed with two SPME methods followed by GC-MS but using CLD labelled with $\mathrm{C}_{13}$ as an internal standard or the proposed method. Results and discussion. The detection (LOD) and quantitation (LOQ) limits of our SPME extraction procedure were determined for GC-MS and GC-MS/MS with water, plant (pineapple roots) and soil samples: in water for MS/MS, $\mathrm{LOD}_{\mathrm{MS} / \mathrm{MS} \text {-water }}=0.5 \mathrm{ng} \cdot \mathrm{L}^{-1}, \mathrm{LOQ}_{\mathrm{MS} / \mathrm{MS} \text {-water }}=2.0 \mathrm{ng} \cdot \mathrm{L}^{-1}$; in andosol for MS $/ \mathrm{MS}$, LOD $\mathrm{LS}_{\mathrm{MS} \text {-soil }}=$ $15.0 \mathrm{ng} \cdot \mathrm{kg}^{-1} \mathrm{dw}$, LOQ $\mathrm{MS} /$ MS-soil $=80.0 \mathrm{ng} \cdot \mathrm{kg}^{-1} \mathrm{dw}$. Data from the seventy contaminated soils obtained with the proposed method and the standard method showed a correlation coefficient of $r=$ 0.86. Data obtained by the two SPME/GC-MS quantitation procedures showed a correlation of $r=$ 0.8073 . Conclusion. The method proposes a simplified sample preparation and extraction of CLD in water, plant and soil samples, with no solvent manipulation and which is not time-consuming. The LOD and LOQ were similar to those obtained with other currently used methods. The method is reliable and accurate and may be considered as a good tool for research purposes.

France (Martinique) / chlordecone / extraction / analytical methods / quantitative analysis / water analysis / soil analysis / tissue analysis

Micro-extraction en phase solide et chromatographie en phase gazeusespectrométrie de masse pour la détermination quantitative de la chlordécone dans les échantillons d'eau, de plantes et de sols.

Résumé - Introduction. La chlordécone (CLD), organochloré autrefois utilisé contre le charançon noir du bananier, est fortement adsorbée sur les sols, comme les andosols. Une procédure simplifiée pour la détermination quantitative des résidus de CLD dans l'eau et des micro-échantillons de sol et de plantes a été comparée à une méthode standard. Matériels et méthodes. La procédure associe un échantillonnage simplifié, une micro-extraction en phase solide (SPME) de 10 min, une séparation par chromatographie en phase gazeuse (GC) et une identification par spectrométrie de masse (MS et MS/MS). La quantification est basée sur une méthode d'ajouts dosés. Soixante-dix échantillons ont été analysés en utilisant la méthode proposée et la méthode standard (extraction par solvant à chaud). Quinze échantillons de sol ont été analysés par deux méthodes SPME GC-MS, mais avec comme étalon interne la $\mathrm{CLD} \mathrm{C}_{13}$ ou la méthode proposée. Résultats et discussion. Les limites de détection (LOD) et de quantification (LOQ) ont été déterminées pour la GC-MS et la GC-MS/MS dans l'eau, dans des plantes (racines d'ananas) et dans les sols : dans l'eau pour la MS/MS, LOD $\mathrm{MS}_{\mathrm{MS}-\mathrm{eau}}=0,5 \mathrm{ng} \cdot \mathrm{L}^{-1}$, $\mathrm{LOQ}_{\mathrm{MS} / \mathrm{MS} \text {-eau }}=2,0 \mathrm{ng} \cdot \mathrm{L}^{-1}$; dans des andosols pour la MS $/ \mathrm{MS}, \mathrm{LOD} M \mathrm{MS} / \mathrm{MS}-\mathrm{sol}=15,0 \mathrm{ng} \cdot \mathrm{kg}^{-1} \mathrm{~ms}$, $\mathrm{LOQMS}_{\mathrm{MS}-\mathrm{sol}}=80,0 \mathrm{ng} \cdot \mathrm{kg}^{-1} \mathrm{~ms}$. Les données provenant des 70 sols contaminés obtenus avec la méthode proposée et la méthode standard ont montré une corrélation de $r=0,86$. Les données obtenues par les deux procédures de quantification SPME / GC-MS ont montré une corrélation $r=0,8073$. Conclusion. La méthode propose un échantillonnage et une extraction de CLD simplifiés dans des échantillons d'eau, de plantes et de sol, sans manipulation de solvants. Les LOD et LOQ sont similaires à celles des méthodes usuelles. La méthode, fiable et précise, est un bon outil pour la recherche.

France (Martinique) / chlordécone / extraction / technique analytique / analyse quantitative / analyse de l'eau / analyse de sol / analyse de tissus 


\section{Introduction}

In the past, chlordecone (IUPAC name decachloropentacyclo $\quad\left[5 \cdot 3 \cdot 0 \cdot 0^{2,6} \cdot 0^{3,9} \cdot 0^{4,8}\right]$ decan-5-one), an organochlorine insecticide, was widely used to control the banana black weevil in the French West Indies (FWI), and became a major soil and water contaminant [1], including sea biota [2]. Due to chronic exposure, this environmental pollutant is potentially dangerous for human health [3-5]. In the near future, other chlordecone environmental 'problems' may come to light in other countries because most of the pesticide produced in the 1970s was exported to Europe for the control of the Colorado potato beetle, mainly in east European countries [6], and to Cameroon and Jamaica for control of the black weevil in banana [7].

Chlordecone has a low water solubility [(0.35 to 3.0) $\left.\mathrm{mg} \cdot \mathrm{L}^{-1}[8]\right)$ and a strong persistence in the environment. It is also strongly adsorbed on soils, particularly on andosols rich in allophane clay and organic matter. The persistence of chlordecone in soils is due to its high affinity for organic matter $\left(2.5<\mathrm{Koc}<20 \mathrm{~m}^{3} \cdot \mathrm{kg}^{-1}\right)[1]$ and its chemical structure (bis-homocubane), which make it poorly susceptible to biodegradation (figure 1). In addition, allophane clay aggregates in andosols have a tortuous fractal microstructure [9-11] which may also play a role in chlordecone sequestration [11-13].

Attempts have already been made, first, to understand the mechanisms of soil, plant and animal contamination [14], and then to look for remediation solutions. These studies pointed to the need for accurate methods of extraction and analysis in different matrices (water, soil, plants). Little literature is specifically dedicated to chlordecone analysis in environmental samples. The chlordecone extraction methods require solvent manipulations in order to be as exhaustive as possible and may be time-consuming. Usually, liquid-liquid extraction and solvent extraction (cold [15-17], hot [18] or hot and under high pressure [19, 20]) are, respectively, done for aqueous samples, and solid plant and soil samples. Detection can be done with different very sensitive techniques and quantitation methods are based on calibration curves of chlordecone in solvent and spiked samples: GC-MS, GC-MS/ MS, GC-ECD or LC-MS and LC-MS/MS analysis. A relatively poor recovery $(80 \%)$ of chlordecone compared with other pesticides was reported for soil samples [20, 21]. The French standard method for measuring inorganic and organic micropollutants NF XP P 41-250-1, 2, 3 [22] is also based on chlordecone solvent extraction. Few attempts have been made to simplify the chlordecone extraction and analysis protocol. XAD-2 resin was tested on river water but required 20-L samples, filtration and finally, extraction by solvent [23]. Near-Infrared Spectroscopy (NIRS) has been tentatively used for solid soil samples [24], allowing fast and cheap determination of chlordecone contamination in soil. Nevertheless, consistent results were only obtained on andosols, so further investigations are required to determine if the NIRS method is valid or not.

Pesticides can be rapidly extracted by SPME (solid phase microextraction) in aqueous solution and in different matrices $[25,26]$. It has been proposed that quantitative measurements of dissolved compounds can be made even before the equilibrium between the solution and the SPME fibre is reached [27]. The SPME technique has been described as a good way to minimise solvent consumption [28]. It could be used as a quantitative method in the case of many pesticides in water [29-31] and in the case of pyrethrinoids in fruits, where the recovery of the molecules was shown to be close to $100 \%$ [32]. For micropollutants in drinking water, SPME was described to be a useful tool for screening [33]. Pesticides with high Koc such as chlordecone are not easily released from the solid matrix into the water and only a small part is actually solubilised, hence rendering quantitation difficult. A SPME/GC-ECD method was described for chlordecone quantitation in fish using PDMS fibre, but which also required a preextraction step using a Soxhlet technique [34]. Analyses of spiked samples using this method showed a recovery rate of about $70 \%$.

Our paper presents a sensitive and accurate automated SPME extraction procedure 
followed by GC-MS (or GC-MS/MS) analysis in small water, plant and soil samples (test portion $=500 \mathrm{mg}$ for soil and plants) for quantitative analyses of chlordecone. Direct SPME extraction is carried out for water samples and calculations using a calibration curve of chlordecone standard in ultrapure water. Meanwhile, quantitation for plant and soil samples required a modified standard addition method with the zero-intercept calculation $[35,36]$. The method enabled the problem of difficult exhaustive extraction of chlordecone from samples and solvent manipulation to be overcome. For water samples, a national inter-laboratory trial allowed the comparison of the data obtained with the SPME extraction/GC-MS method with liquid/liquid extraction methods in other laboratories. Then, duplicated plant and soil samples were analysed in the CIRAD laboratory in the FWI using the proposed method and were also analysed with the normalised method 'NF XP P 41-250-1, 2, 3' by the Laboratoire Départemental d'Analyse (LDA26 in Drôme, France, a laboratory accredited for pesticide analysis). This method was used as a reference method for chlordecone estimations in our samples. Then, another set of duplicated soil samples were analysed using the proposed method in the CIRAD laboratory in the FWI and a second SPME/GC-MS method in which quantitation was done with chlordecone labelled with $\mathrm{C}_{13}$ as an internal standard in the CIRAD laboratory in Montpellier (France). The advantages, drawbacks and limits of the methods are discussed.

\section{Experimental}

\subsection{Water samples}

An inter-laboratory trial for chlordecone analysis in water was organised by BRGM in Orléans (France) [37], which provided two types of water samples (two duplicates each) from a continental surface water $\left(0.3 \mu \mathrm{g} \cdot \mathrm{L}^{-1}\right)$ and from an underground river $\left(0.1 \mu \mathrm{g} \cdot \mathrm{L}^{-1}\right)$. In our laboratory, the samples

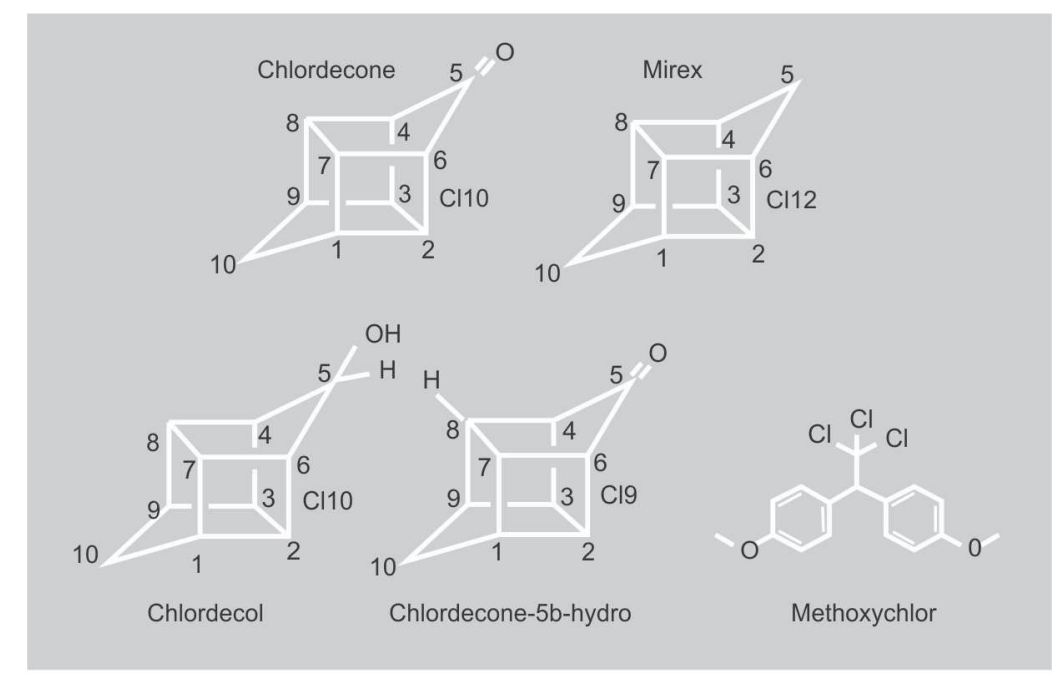

were used as received with no further preparation. They were directly analysed by SPME/GC-MS after addition of the internal standard (e.g., $250 \mu \mathrm{L}$ of a metoxychlor solution $37.5 \mu \mathrm{g} \cdot \mathrm{L}^{-1}$ in ultrapure water) with a calibration curve of chlordecone in water (see \$3.3.1). All other ten laboratories used solvent extraction and MS or MS/MS detection after GC or LC separation. The results validated the use of SPME as a good and simple extraction method for chlordecone analyses in water samples (table I). A reference solution of chlordecone $\left(2000 \mu \mathrm{g} \cdot \mathrm{L}^{-1}\right)$ in cyclohexane was then diluted in acetone then in water for SPME extraction in order to give a solution within the range of the chlordecone concentration of the calibration curve $\left(\sim 2 \mu \mathrm{g} \cdot \mathrm{L}^{-1}\right)$.

\subsection{Plant and soil samples}

Chlordecone measurements were made using both soil samples (andosols and ferralsols) and plant samples (pineapple roots). Andosols are known in the FWI for their high chlordecone retention capability compared with other types of soils [24, 38]. Pineapple in the FWI is often grown on previously contaminated banana plots, meaning pineapple is potentially one of the most contaminated crops.

For preparation of samples and sub-samples, soil samples (200 g) and plant samples (20 g) were partly air-dried overnight at
Figure 1.

Molecular structures of chlordecone (decachloropentacyclo[5.3.0.0 $0^{2,6} \cdot 0^{3,9} \cdot 0^{4,8}$ ]decan5-one), Mirex (dodecachloropentacyclo[5.3.0.02,6.03, $9.04,8]$ decane), chlordecol (decachloropentacyclo [5.3.0.0 $0^{2,6} \cdot 0^{3,9} \cdot 0^{4,8}$ ]decan-5-ol), chlordecone-5b-hydro $(1,2,3,4,6,7,9,10,10$-nonachloropentacyclo $\left[5 \cdot 3 \cdot 0 \cdot 0^{2,6} \cdot 0^{3,9} \cdot 0^{4,8}\right]$ decan-5-one) (carbon number in IUPAC System) and methoxychlor (1,1,1-trichloro-2,2bisethane). 
Table I.

French national inter laboratories trial for chlordecone analyses in water samples [37].

\begin{tabular}{|c|c|c|c|c|c|c|}
\hline \multirow[t]{3}{*}{ Samples } & \multicolumn{2}{|c|}{ [Chlordecone] } & \multirow[t]{2}{*}{ Average bias SPME } & \multicolumn{3}{|c|}{ Global bias } \\
\hline & Actual value & SPME & & $\max$ & $\min$ & average \\
\hline & \multicolumn{2}{|c|}{$\left(\mu \mathrm{g} \cdot \mathrm{L}^{-1}\right)$} & \multicolumn{4}{|c|}{$(\%)$} \\
\hline Underground water & 0.102 & $\begin{array}{l}0.104 \\
0.109\end{array}$ & 4 & 71 & 3 & 36 \\
\hline Superficial water & 0.304 & $\begin{array}{l}0.320 \\
0.317\end{array}$ & 5 & 85 & 2 & 25 \\
\hline Standard solution & 2002.0 & $\begin{array}{l}2189.0 \\
1880.0\end{array}$ & 2 & 104 & 2 & 24 \\
\hline
\end{tabular}

$70{ }^{\circ} \mathrm{C}$ with no further control of the exact residual humidity. Soil samples were then homogenised in a Retsch $^{\circledR}$ soil grinder $(\max 100 \mu \mathrm{m})$. Plant samples were ground in an 'IKA A11 ${ }^{\circledR}$ grinder. SPME extraction requires the samples to be prepared as water suspensions. To this end, an aliquot of $500 \mathrm{mg}$ of the partially dried and homogenised soil or plant samples (or $1-5 \mathrm{~g}$ of fresh weight) were ground for $10 \mathrm{~min}$ in $20 \mathrm{~mL}$ of distilled water with an automatic stainless steel mortar ('Pulverisette 2 , ${ }^{\circledR}$, Fritsch) in order to obtain an extremely thin suspension. The suspension was then diluted to $100 \mathrm{~mL}$ with ultrapure water.

For quantitation, a standardised sub-sampling procedure was used: four $1-\mathrm{mL}$ subsamples of the suspension were removed with an automatic pipette under magnetic stirring at controlled speed at a depth of 2/ 3 of the height of the stirred suspension in a 150-mL glass beaker specifically dedicated to this procedure, and then transferred into pre-weighed 20-mL SPME vials. The internal standard was added to the sub-samples in the SPME vials and ultrapure water was added to bring the final volume to $18.5 \mathrm{~mL}$.

The repeatability of the sub-sampling procedure was validated on two different soils and pineapple roots with ten $1-\mathrm{mL}$ sub-samples. They were dried at $80^{\circ} \mathrm{C}$ for $5 \mathrm{~h}$, and kept overnight under a dry atmosphere with silica gel. Then the dry residues were determined on an electronic scale $( \pm 0.01 \mathrm{mg})$, and means and standard deviations $(\alpha=0.05 \mathrm{mg})$ were calculated.

\subsection{Optimisation of SPME conditions (fibre, temperature and time)}

PDMS/DVB fibres (polydimethylsiloxane/ divinylbenzene, $65 \mu \mathrm{m}$ ) from Supelco (Bellefonte, PA, USA) were used with an automated extracting and injecting device (CombiPal ${ }^{\circledR}$, CTC Analytics, Zwingen, Switzerland). Different sets of temperatures and extraction times were tested to optimise the extraction procedure. The sub-samples were preheated at $40{ }^{\circ} \mathrm{C}, 60^{\circ} \mathrm{C}$ or $80^{\circ} \mathrm{C}$ for 5 min. Then, SPME extraction $[(5,10$ or 30) $\min$ at $40{ }^{\circ} \mathrm{C}, 60^{\circ} \mathrm{C}$ or $80^{\circ} \mathrm{C}$ ] was performed under stirring at $250 \mathrm{rpm}$. The fibre was desorbed directly into the GC injector at $270{ }^{\circ} \mathrm{C}$ for $5 \mathrm{~min}$. Finally, the fibre was cleaned under a nitrogen stream for $30 \mathrm{~min}$ at $250{ }^{\circ} \mathrm{C}$ during the $\mathrm{GC}$ analysis. It was verified that this cleaning procedure avoided any carryover between two analyses. The optimisation was done on a contaminated andosol sample, $3.87 \mathrm{mg} \cdot \mathrm{kg}^{-1}$ dry weight (dw) and one chlordecone standard solution in water $2.16 \mu \mathrm{g} \cdot \mathrm{L}^{-1}$, then a second one at low concentration, $0.36 \mu \mathrm{g} \cdot \mathrm{L}^{-1}$. The objective of the optimisation was to find a compromise between the total time required for analysis, and sensitivity and accuracy.

\subsection{Selection of internal standards}

The internal standard selection was an important preliminary step because SPME 
extraction is performed in a complex medium. In this medium, the soil or the organic matter is suspended in water, so the molecules are partly adsorbed onto the solid part of the matrix, partly dissolved in the water and partly adsorbed on the SPME fibre. Consequently, the main criterion for internal standard selection was the similarity of their behaviour under the SPME extraction procedure with organic matter or soil suspension in water in the range of chlordecone concentrations and the amounts of soil or organic matter we were working with.

For internal standard selection, increasing quantities of soil or organic matter (andosols and pineapple root samples) were added to pure solutions containing increasing concentrations of different organochlorines [methoxychlor, hexachlorobenzene (HCLB) and dieldrin] and chlordecone. The extractions and analyses were done by SPME/GC-MS and the data obtained for the organochlorines compared with those from chlordecone. The methoxychlor (Metox, IUPAC name: 1,1,1-trichloro-2,2-bisethane) showed very similar uptakes by the SPME fibre to the chlordecone ones at the different concentrations tested (normalised ratio peak areas [organochlorines/chlordecone] of about 1.0 for the different amounts of soil and roots, mean obtained from four different chlordecone concentrations, figure 2).

Molecules showing more structural similarities with chlordecone, e.g., chlordecol, or chlordecone-5b-hydro, or Mirex were discarded (figure 1) because they have been detected in chlordecone commercial standards at, respectively, 4.0\%, $0.5 \%$ and $0.4 \%$ (pers. commun., C. Mouvet, BRGM). In addition, Mirex has been commonly used as an insecticide in the FWI unlike methoxychlor.

Finally, chlordecone labelled with $\mathrm{C}_{13}$ (chlordecone- $\mathrm{C}_{13}$ ) would probably have been the best choice in terms of structural similarities and behaviour under SPME extraction. However, it is expensive for routine analyses, and so was only used for validation of the method using a protocol and a calculation method based on different $\mathrm{m}$ / $z$ ratios and analyses being done in two different CIRAD laboratories.

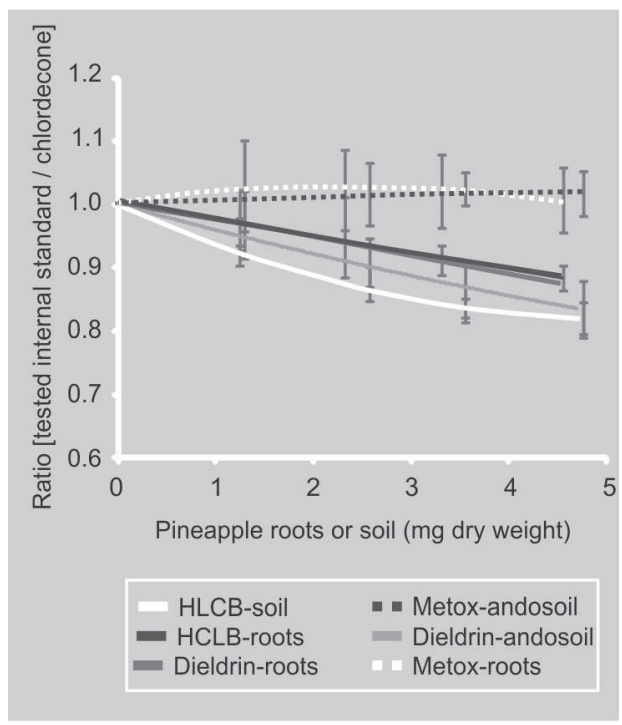

Figure 2.

Ratio peak area of 'tested internal standard' vs. chlordecone in the presence of increasing organic matter or soil ratios [tested internal standard peak areas / chlordecone peak areas] versus the amount of dry pineapple roots.

Data were obtained from pure solutions of organochlorines tested as internal standards and chlordecone, then internal standard data were normalised against chlordecone data. Means were obtained with four concentrations of pesticides: $(0.72,2.17,4.34$ and 7.23) $\mu \mathrm{g} \cdot \mathrm{L}^{-1}$ of chlordecone. HCLB: hexachlorobenzene.

\subsection{Instrumentation and GC-MS and GC-MS/MS operating conditions}

Chlordecone analyses were performed on a GC450/MS240 (Varian, USA), separation on a non-polar column: RTX-1ms (Restek, USA), $15 \mathrm{~m}, 0.25 \mathrm{~mm}$ ID, $0.25 \mu \mathrm{m} \mathrm{d}_{\mathrm{f}}$, with $\mathrm{He}$ (purity N60) as the carrier gas with a constant flow rate of $1 \mathrm{~mL} \cdot \mathrm{min}^{-1}$. The injector temperature was constant at $270{ }^{\circ} \mathrm{C}$, and 5 min splitless during fibre desorption followed by a split ratio of 1:50 during analysis. The oven programme was $100^{\circ} \mathrm{C}$ (held $5 \mathrm{~min}$ ), then $30^{\circ} \mathrm{C} \cdot \mathrm{min}^{-1}$ up to $160^{\circ} \mathrm{C}$, then $8^{\circ} \mathrm{C} \cdot \mathrm{min}^{-1}$ up to $250^{\circ} \mathrm{C}$, then $30^{\circ} \mathrm{C} \cdot \mathrm{min}^{-1}$ up to $300{ }^{\circ} \mathrm{C}$ (held $5 \mathrm{~min}$ ). The mass detector was a MS240 (Varian, USA) ion trap operating in electron impact ionisation (EI) mode $(70 \mathrm{eV})$.

In the MS method the detection of chlordecone was done using the ions $\mathrm{m} / \mathrm{z}(272+$ 274) and $\mathrm{m} / \mathrm{z} 237$ (37\%) as qualifiers. The ion $\mathrm{m} / \mathrm{z} 355$ was discarded because it is also a product of siloxanes from the PDMS/DVB fibre. For Metox, the ion m/z 227 was used for detection and quantification. The main ion $\mathrm{m} / \mathrm{z} 272\left(\mathrm{C}_{5} \mathrm{Cl}_{6}\right)$ results from the symmetric splitting of the cage-like structure of chlordecone (bis-homocuban family).

In the MS/MS method, only one parent ion was selected, in resonance mode, for the chloredecone $(\mathrm{m} / \mathrm{z} 272)$ and for Metox $(\mathrm{m} / \mathrm{z} 227)$. The trapping energy selected was 
$\mathrm{Qz}=0.4$ and the excitation energy was $1.8 \mathrm{~V}$. This resulted in the daughter ions $\mathrm{m} /$ z 237 and $\mathrm{m} / \mathrm{z}(212+196)$, respectively, for chlordecone and Metox. The ion trap system allowed reducing the number of daughter ions and these ions (and a few $\mathrm{m} / \mathrm{z}$ around these masses, as m/z 235 and 239 also issued from 272) represent almost $100 \%$ of the ions produced by the electronic impacts. The $\mathrm{m} / \mathrm{z} 235$ and $\mathrm{m} / \mathrm{z} 239$ were used as qualifiers (59\% and 49\%).

The MS/MS method was developed to confirm the presence of chlordecone in environmental samples where there may be possible interferences due to the matrix, particularly at very low chlordecone concentrations $\left(<0.5 \mu \mathrm{g} \cdot \mathrm{L}^{-1}\right.$ in the water suspension or about $1 \mu \mathrm{g} \cdot \mathrm{kg}^{-1}$ in soil), which reduce the noise signal.

\subsection{Quantitation}

The chlordecone quantitation in water samples (two replicates) was based on simple comparison with a calibration curve with a chlordecone standard solution in water $\left(0.29-10.0 \mu \mathrm{g} \cdot \mathrm{L}^{-1}\right)$. The chlordecone quantitation for plant and soil samples was done using a standard addition method to calculate the zero intercept. This method compensates for incomplete SPME extraction and decreases the systematic error. We took into account the model developed by $\mathrm{Ai}$, who showed that quantitative measurement after extraction by SPME is possible in nonequilibrium situations [27]. This dynamic model, which is based on a diffusion-controlled mass transfer process applied to SPME, states that a linear relationship exists between the adsorbed analyte and its initial concentration in the sample matrix before equilibrium is actually reached. We used this characteristic to reduce soaking of the SPME fibre to the minimum time required for chlordecone quantitation.

The standard addition was done as follows: four 1-mL sub-samples of the same water suspensions, using the standardised sub-sampling procedure described above, were spiked with chlordecone, giving four concentrations of added chlordecone of, respectively, $(0.00,0.72,1.44$ and
2.16) $\mu \mathrm{g} \cdot \mathrm{L}^{-1}$, in a final volume of $18.5 \mathrm{~mL}$. The final internal standard concentration was $0.5 \mu \mathrm{g} \cdot \mathrm{L}^{-1}$. The chlordecone standard was prepared from $10 \mathrm{mg}$ pre-weighed vials of chlordecone (AccuStandards ${ }^{\circledR}$, 99.7\% GC-MS), diluted in $100 \mathrm{~mL}$ of methanol followed by two subsequent dilutions in water up to $53 \mu \mathrm{g} \cdot \mathrm{L}^{-1}$. Then, by linear regression, the actual concentrations of the solid samples were estimated assuming that, in our conditions, the ratio 'chlordecone adsorbed on the particles in the suspension versus chlordecone dissolved in water' (and hence accessible to fibre uptake) is the same for both the added chlordecone and the initial contamination to be evaluated. This important hypothesis is discussed in the 'results and discussion' section below. Data were accepted only when the linear regression for both the chlordecone peak area and ratios [chlordecone peak area / internal standard peak area] against the added chlordecone concentrations from the four replicates gave $R^{2}>0.995$.

\subsection{Test of the method}

First, the repeatability of the analyses with this SPME/GC-MS method was validated. Ten replicates of nine different soil samples were analysed. The samples were as follows: a mixture of different soils used as a reference with a chlordecone contamination of $3.6 \mathrm{mg} \cdot \mathrm{kg}^{-1}$, and four andosols and four ferralsols with different chlordecone contaminations ranging from (0.26 to 5.66) $\mathrm{mg} \cdot \mathrm{kg}^{-1}$ [Laboratoire Départemental d'Analyse (LDA26) data], representative of the range of contamination observed in Martinique soils. Chlordecone concentrations were measured and compared with LDA26 data.

Second, the method was validated on 70 andosol samples with different levels of allophane clay and organic matter contents, analysed with two methods: first, with the proposed method in our laboratory, then with the LDA26 method (hot solvent extraction followed by GC-MS). The correlation between the two sets of data was calculated.

Third, we compared the proposed quantitation method in the CIRAD Martinique 
Table II.

Variability of the $1 \mathrm{~mL}$ sub-sample dry weights from a water suspension $(100 \mathrm{~mL})$ of $500 \mathrm{mg}$ of soil or organic matter samples under magnetic stirring.

\begin{tabular}{lcc} 
Type of sample & $\begin{array}{c}\text { Dry weight of the sub-sample effectively taken } \\
(\mathrm{mg})\end{array}$ & $\begin{array}{c}\text { Standard deviation } \\
\text { (equivalent in \%) }\end{array}$ \\
\hline Andosol & $4.99 \pm 0.33$ & 6.71 \\
Ferralsol & $5.36 \pm 0.35$ & 6.48 \\
Pineapple roots & $4.81 \pm 0.28$ & 5.76 \\
\hline Standard deviations are calculated on ten replicates. &
\end{tabular}

laboratory using the same SPME procedure but followed by GC-MS analyses with chlordecone- $\mathrm{C}_{13}$ as an internal standard in the CIRAD Montpellier laboratory. In that case, the quantitation was based on the $\mathrm{m} / \mathrm{z}$ ratios. Resulting from hexachlorocyclopentadien condensation, eight $\mathrm{C}_{13}$ isotopes were introduced into the molecule structure (Innovation \& Chimie Fine, Manosque, France). The MS quantifying method with chlordecone- $\mathrm{C}_{13}$ as an internal standard is carried out in SIM mode. Focused on the main fragment $\mathrm{C}_{5} \mathrm{Cl}_{6}$, four quantifying ions and one qualifying ion $\mathrm{m} / \mathrm{z} 270,272$, 279,280 and 276, respectively, were selected. Because of the isotopic configuration of chlorine and many doublet interferences, the simple use of the major ions in the co-eluted molecules was prohibited. A mean spectra, subtracted by the mean noise, was taken at the apex of the chlordecone chromatographic peak. Calibrations, based on $270 / 279,270 / 280,272 / 279$ and $272 / 280$ ratios, were calculated from increasing amounts of chlordecone $[(0,50,100$ and 600) ng] compared with $100 \mathrm{ng}$ of chlordecone $_{13}$. Coefficients of determination ranged from 0.9996 to 0.9999 .

The correlation between the two sets of data was calculated. The test focused on the comparison between the standard addition calculation with Metox as an internal standard and the direct calculation from a calibration curve with chlordecone- $\mathrm{C}_{13}$ as an internal standard. Direct calculation was possible with chlordecone- $\mathrm{C}_{13}$ because it was expected to exhibit exactly the same behaviour under the SPME technique as the chlordecone.

\section{Results and discussion}

\subsection{The sub-sampling procedure from water suspensions}

An important element to be taken into account is the representativeness of such small sub-samples with respect to the original samples. That is why it was very important to perform grinding in two steps, particularly of soils, to ensure a homogeneous water suspension under stirring. Finally, standardising the sub-sampling procedure by using an automatic pipette was also an important step for accuracy of the analyses as it reduced the variability of the dry weight of the sub-samples.

The sub-samples, $1 \mathrm{~mL}$ of the suspension (500 mg dry sample in $100 \mathrm{~mL}$ of water), corresponded to a dry weight of about $5 \mathrm{mg}$ (table II). For the three types of samples, two different soil samples and one root sample, the standard deviations ranged from 5\% to $7 \%$, indicating satisfactory repeatability of the sub-sampling method for these very small samples.

It is important to note that, at this stage of the sampling procedure, the samples were not necessarily completely dry. The dry weights of the sub-samples were actually determined after SPME extraction and GC-MS analysis. They were dried directly in 
the pre-weighed vials and the data used for the subsequent calculation of contaminations was expressed in chlordecone $\mathrm{mg} \cdot \mathrm{kg}^{-1}$ dry weight.

Nevertheless, we also checked that calculating a dry weight mean on 10 replicated sub-samples taken in the same $100 \mathrm{~mL}$ of water suspension from which the four spiked sub-samples were taken did not affect the accuracy of the quantitation. The dry weight evaluation saved a lot of time because it could be measured the very same day as the analyses instead of $48 \mathrm{~h}$ later when the spiked sub-samples were dried in their pre-weighed vials. Drying $1 \mathrm{~mL}$ of solution was much faster than drying $18.5 \mathrm{~mL}$.

\subsection{Optimisation of SPME conditions (fibre, temperature and time)}

\subsubsection{Selection of SPME fibres}

Three different SPME fibres were tested: a non-polar PDMS fibre - polydimethylsiloxane $(100 \mu \mathrm{m})$, a medium polarity PDMS/DVB fibre - polydimethylsiloxane/ divinylbenzene $(65 \mu \mathrm{m})$ and a CAR/PDMS fibre - carboxen (porous carbon coating)/ polydimethylsiloxane $(85 \mu \mathrm{m})$; the CAR/ PDMS fibre and PDMS fibre $(100 \mu \mathrm{m})$ exhibited a lower extraction rate for chlordecone than the PDMS/DVB fibre. For example, the limit of detection in water with a GC-MS detector was, respectively, $72.0 \mathrm{ng} \cdot \mathrm{L}^{-1}$ and $35.0 \mathrm{ng} \cdot \mathrm{L}^{-1}$ using the PDMS fibre and the PDMS/DVB fibre, but the PDMS fibre can be cleaned faster than the PDMS/DVB fibre ( $15 \mathrm{~min} v s .30 \mathrm{~min}$ ). The CAR/PDMS fibre produced many additional peaks and interferences during GC analyses. These observations were consistent with those made in a polychlorobiphenyl study using the SPME technique [25], and finally led to our choice of the PDMS/DVB fibre for analyses.

3.2.2. Extraction temperature and extraction time of the fibre in the water suspension

Increasing the extraction temperature $\left(40^{\circ} \mathrm{C}\right.$, $60{ }^{\circ} \mathrm{C}$ or $80^{\circ} \mathrm{C}$ ) increased the MS signals by $1.1\left(60{ }^{\circ} \mathrm{C}\right.$ compared with $\left.40{ }^{\circ} \mathrm{C}\right)$ and 1.8 $\left(80{ }^{\circ} \mathrm{C}\right.$ compared with $40{ }^{\circ} \mathrm{C}$ ) for chlordecone. The temperature $80{ }^{\circ} \mathrm{C}$ was retained for the extraction procedure.

The chlordecone SPME uptakes from a soil sample (chlordecone: $3.87 \mathrm{mg} \cdot \mathrm{kg}^{-1} \mathrm{dw}$ ) suspended in water increased linearly from 5 min to $30 \mathrm{~min}(\times 5.4)$ and increased only 1.8 times for the chlordecone standard solution at $2.16 \mu \mathrm{g} \cdot \mathrm{L}^{-1}$.

In the experiments at a low concentration of chlordecone (a standard solution of chlordecone in water at $0.36 \mu \mathrm{g} \cdot \mathrm{L}^{-1}$, which could be representative of what is currently available in water suspensions of our environmental samples) an increased uptake was observed from $5 \mathrm{~min}$ to $10 \mathrm{~min}$ then to $20 \mathrm{~min}\left(\right.$ at $80{ }^{\circ} \mathrm{C}$ ) by, respectively, 106.3\% and $165.0 \%$. The limit of quantitation is often determined by a S:N ratio of 10 (chlordecone peak signal versus baseline noise signal). These ratios were 14, 28 and 45 for, respectively, (5, 10 and 20) min. Consequently, because the objective was to reduce the time required for the total procedure 'extraction plus analysis' to the minimum, we determined that a $10-\mathrm{min}$ extraction was still acceptable for chlordecone analyses in these conditions.

The linear increase in uptake between (5 and 30) min also showed that the equilibrium between the chlordecone adsorbed on the fibre and the dissolved chlordecone was in any case not reached, as previously observed with other pesticides, not even after $2 \mathrm{~h}$ of extraction [27, 33].

\subsection{Calibrations}

\subsubsection{SPME/GC-MS calibration and limits of detection and quantitation}

The chlordecone uptake with the SPME/GCMS procedure, measured by the ratio [chlordecone peak area/ internal standard peak area] from a standard chlordecone solution in water, increased linearly versus the chlordecone concentration in the range of 0.29$10.0 \mu \mathrm{g} \cdot \mathrm{L}^{-1}$ with $R^{2}=0.9974$ (figure $3 a$ ). Meanwhile, the Metox uptake (internal standard at $0.5 \mu \mathrm{g} \cdot \mathrm{L}^{-1}$ ) was constant when 
chlordecone concentration increased [27, 29, 33].

With this SPME/GC-MS method (10 min extraction), the detection and quantitation limits were in water samples: LOD ${ }_{\text {MS-water }}=$ $35.0 \mathrm{ng} \cdot \mathrm{L}^{-1} \quad$ ([signal:noise $]=3$ ), and $\mathrm{LOQ}_{\mathrm{MS} \text {-water }}=80.0 \mathrm{ng} \cdot \mathrm{L}^{-1}$ ([signal:noise $]=$ $10)$, the LOD and LOQ measured by successive dilution until [signal:noise] $=3$ or 10 were reached; and in soil samples: LOD $_{\text {MS-soil }}=0.05 \mathrm{mg} \cdot \mathrm{kg}^{-1}$, and LOQ MS-soil $=$ $0.2 \mathrm{mg} \cdot \mathrm{kg}^{-1}$ (measured on andosols with high retention properties due to their allophane and organic matter contents, as explained above). Therefore, the LOD and LOQ determined on andosol and root samples were not significantly different, probably because andosols are rich in organic matter and allophane clay and have a strong retention capability for chlordecone.

\subsubsection{SPME/GC-MS/MS calibration at low chlordecone concentrations and limits of detection and quantitation}

In the MS/MS method, calibration was made between $4.3 \mathrm{ng} \cdot \mathrm{L}^{-1}$ and $138.6 \mathrm{ng} \cdot \mathrm{L}^{-1}$ of chlordecone in water using the same SPME procedure for $10 \mathrm{~min}$ at $80{ }^{\circ} \mathrm{C}$. The ratio [chlordecone peak area/ internal standard peak area] was linearly correlated with the chlordecone concentration (figure 3b). The [signal:noise] ratios were good for quantitation, ranging from 68 to 1163

In our conditions, with this method, the limit of detection was $\mathrm{LOD}_{\mathrm{MS} / \mathrm{MS} \text {-water }}=$ $0.5 \mathrm{ng} \cdot \mathrm{L}^{-1}$ in water, while the limit of detection on andosol determined in the water suspension was $\mathrm{LOD}_{\mathrm{MS} / \mathrm{MS} \text {-soil }}=15 \mathrm{ng} \cdot \mathrm{kg}^{-1} \mathrm{dw}$. The limits of quantitation were $\mathrm{LOQ}_{\mathrm{MS} / \mathrm{MS} \text {-water }}=$ $2.0 \mathrm{ng} \cdot \mathrm{L}^{-1}$ in water and $\mathrm{LOQ}_{\mathrm{MS} / \mathrm{MS} \text {-soil }}=$ $80 \mathrm{ng} \cdot \mathrm{kg}^{-1} \mathrm{dw}$ in soil (with [signal:noise] = 10).

These data show that it is reasonable to measure chlordecone contamination in water under the LMR level (European Norm $\mathrm{LMR} \leq 0.05 \mu \mathrm{g} \cdot \mathrm{L}^{-1}$ in water; Reg. (EC) No $839 / 2008$ ) and this is also the case for plant and soil samples in water suspensions, at least when the chlordecone released into the water suspension is within this range of concentrations.

It should be noted that these limits are related to the short chlordecone extraction

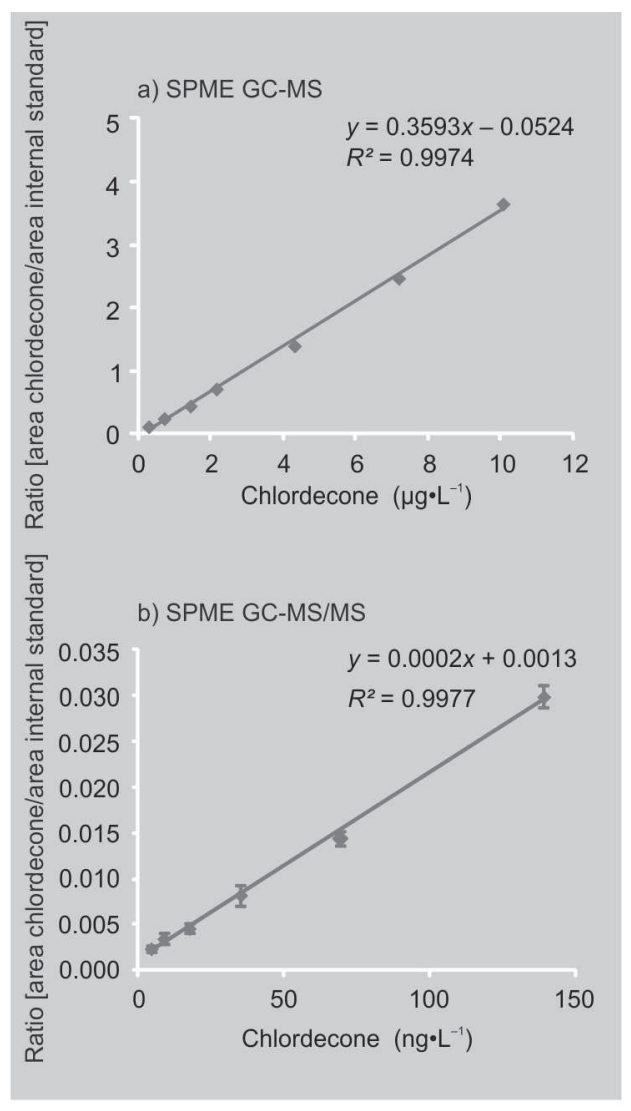

Figure 3.

a) Calibration curve of chlordecone in water (SPME GC-MS).

b) Calibration curve of chlordecone in water (SPME GC-MS/MS).

SPME/GC-MS and MS/MS calibration for chlordecone in water with Metox as an internal standard. Means of three replicates. For the low concentration (MS/MS) the ratio [signal:noise] ranged from 68 for $4.3 \mathrm{ng} \cdot \mathrm{L}^{-1}$ chlordecone to 1163 for $138.4 \mathrm{ng} \cdot \mathrm{L}^{-1}$ chlordecone. time by SPME (10 $\mathrm{min}$ ) required for our method. One would expect lower limits with a longer extraction time, but this would have been in contradiction with our objective of defining a rapid analytical procedure.

\subsection{Methods of quantitation for plant (pineapple roots) and soil samples}

\subsubsection{Hypotheses for the quantitation methods}

The quantitation of sample contamination was based on the addition of known amounts of a chlordecone standard solution under the following hypothesis. The assertion made by Ai [27] is also valid for the measurement of chlordecone in a water suspension of a solid sample where the source of the contamination is the solid phase (organic matter or soil) instead of just water when the samples are prepared following our procedure. 
Figure 4.

Chlordeconeanalyses by SPME GC-MS in water suspension of contaminated pineapple roots (30 $\mathrm{mg} \cdot \mathrm{kg}^{-1} \mathrm{dw}$ ).

SPME/GC-MS: ratios [chlordecone peak areas / internal standard peak areas] versus chlordecone concentration in the presence of contaminated pineapple roots.

The pineapples were grown on contaminated soil. The amounts (mg dw) indicated are those weighed in the vial after chlordecone analyses. The ' $0.00 \mathrm{mg}$ ' was the normal calibration curve in water. Internal standard concentration $1.5 \mu \mathrm{g} \cdot \mathrm{L}^{-1}$. Standard deviations for chlordecone analyses and organic matter dry weights from four replicates.
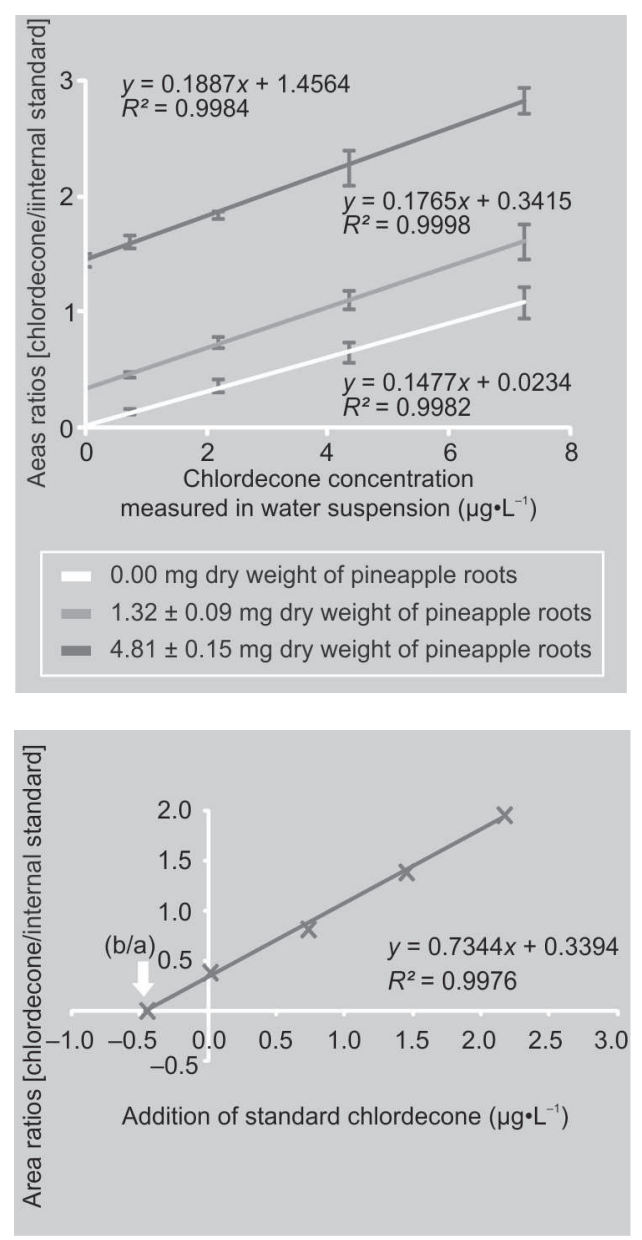

Figure 5.

Quantitation of chlordecone in soil by linear regression on four spiked samples SPME/GC-MS determination of chlordecone contamination in andosol.

The chlordecone available to the SPME fibre in the four spiked samples was given by the peak area and the ratio [chlordecone peak area/internal standard peak area]. The actual total amount of chlordecone in the 'sample' and 'the added chlordecone' was given by the ratio $|b / a|, b$ and $a$ being the coefficients of the linear regression between the chlordecone peak area or ratio [chlordecone/internal standard] vs. added chlordecone concentration, in the form $y=a x+b$. Then the result was expressed in $\mathrm{mg} \cdot \mathrm{kg}^{-1} \mathrm{dw}$, taking into account the average dry weight of ten $1 \mathrm{~mL}$-subsamples of soil in water suspension was $4.6 \mathrm{mg} \mathrm{dw}$. The andosol contamination was also determined by the LDA26 method at $1.57 \mathrm{mg} \cdot \mathrm{kg}^{-1} \mathrm{dw}$.

Calculation method

1) $\mathrm{a}=0.7344 ; b=0.3394$; soil sample $4.6 \mathrm{mg} \mathrm{dw}$ on ten replicates of $1 \mathrm{~mL}$ sub-samples.

2) $X$ intercept: $|\mathrm{b} / \mathrm{a}|=0.46215 \mu \mathrm{g} \cdot \mathrm{L}^{-1}$ (vol. $18.5 \mathrm{~mL}$ ). 3) Soil sample $\mathrm{dw}=4.6 \mathrm{mg}$ in $18.5 \mathrm{~mL}$ (final vol. for SPME).

4) Chlordecone contamination $=1.859 \mathrm{mg} \cdot \mathrm{kg}^{-1} \mathrm{dw}$.
The consequence of this hypothesis is that, in the suspension, the ratio of the chlordecone adsorbed on the solid sample to the chlordecone released in the water suspension is the same for the added chlordecone (increased amounts of standard solution) and the chlordecone from the contaminated sample. If this hypothesis is true, quantitative measurement of chlordecone contamination of solid samples in water suspension should be possible in our conditions of sample preparation. This was confirmed by the experimental data presented hereafter.

\subsubsection{Test of the hypotheses}

The chlordecone uptake by the fibre increased linearly with increasing amounts of chlordecone [range (0.72 to 7.23$) \mu \mathrm{g} \cdot \mathrm{L}^{-1}$ ] added to the suspension of contaminated roots in water. This was observed for different amounts of roots in the water suspension (figure 4). The contamination of roots was estimated at $30 \mathrm{mg} \cdot \mathrm{kg}^{-1} \mathrm{dw}$ by the LDA26 method with hot solvent extraction. This linear increase was also observed on two soil samples, an andosol with chlordecone contamination of $1.5 \mathrm{mg} \cdot \mathrm{kg}^{-1} \mathrm{dw}$, and a ferrasol with chlordecone contamination of $0.36 \mathrm{mg} \cdot \mathrm{kg}^{-1} \mathrm{dw}$ (data not shown).

These data confirmed our initial hypothesis and also showed that the chlordecone contamination of plant and soil samples can be estimated using a simple linear regression and the standard addition method calculating the zero intercept.

\subsubsection{Quantitation of chlordecone contamination of soils and plant root samples by SPME/GC-MS}

In an andosol, the chlordecone contamination was estimated with the linear regression equation in the form $y=a x+b$, where $y=$ ratio [chlordecone/internal standard] and $x=$ "added" chlordecone concentrations, $a=$ slope and $b=$ intercept on the $Y$ axis (figure 5). The "calculated" concentrations given by the intercept of the linear regression curve with the $\mathrm{X}$ axis (calculated as [b/ a]) actually represents what the concentration of the total chlordecone (dissolved plus adsorbed on the soil) would have been in the $18.5-\mathrm{mL}$ water suspension. Then, the 
Table III.

Variability of chlordecone analyses on soil samples with two GC/MS techniques (F.W.I.).

\begin{tabular}{|c|c|c|c|c|}
\hline \multirow[t]{2}{*}{ Soil samples } & \multirow{2}{*}{$\begin{array}{c}\text { LDA26 method } \\
\mathrm{mg} \cdot \mathrm{kg}^{-1} \mathrm{dw}( \pm 30 \%)\end{array}$} & \multicolumn{3}{|c|}{ Proposed SPME method } \\
\hline & & $\mathrm{mg} \cdot \mathrm{kg}^{-1} \mathrm{dw}$ & $\sigma$ & $\sigma(\%)$ \\
\hline Reference 'Soil mixture' & 3.60 & 3.84 & \pm 0.68 & 17.7 \\
\hline Andosol 1 & 1.50 & 1.51 & \pm 0.38 & 25.2 \\
\hline Andosol 2 & 1.12 & 1.25 & \pm 0.09 & 6.8 \\
\hline Andosol 3 & 1.77 & 1.53 & \pm 0.21 & 13.7 \\
\hline Andosol 4 & 5.35 & 5.37 & \pm 0.81 & 15.2 \\
\hline Ferralsol 1 & 0.26 & 0.32 & \pm 0.09 & 28.0 \\
\hline Ferralsol 2 & 0.86 & 0.65 & \pm 0.14 & 21.8 \\
\hline Ferralsol 3 & 1.76 & 1.97 & \pm 0.24 & 12.0 \\
\hline Ferralsol 4 & 5.66 & 5.77 & \pm 0.70 & 12.1 \\
\hline
\end{tabular}

sample dry weight enabled the final calculation to express the chlordecone contamination in $\mathrm{mg} \cdot \mathrm{kg}^{-1}$ dry weight. The result was $1.859 \mathrm{mg} \cdot \mathrm{kg}^{-1} \mathrm{dw}$. The contamination of the soil sample in this experiment was also measured with the GC-MS normalised method with hot solvent extraction in the LDA26: $1.57 \mathrm{mg} \cdot \mathrm{kg}^{-1}( \pm 30 \%)$. Note that the concentrations of the added chlordecone were in the range of the initial sample contamination.

This calculation applied to the pineapple root data for two different amounts of the same contaminated sample gave a contamination of $27.2 \pm 2.4 \mathrm{mg} \cdot \mathrm{kg}^{-1}$ and $29.6 \pm$ $2.7 \mathrm{mg} \cdot \mathrm{kg}^{-1}$, respectively, with (1.32 and 4.81) $\mathrm{mg}(\mathrm{dw})$ of pineapple roots (figure 4 ). Both values were in the range of the LDA26 estimation with hot solvent extraction that gave an estimation of $30.0 \mathrm{mg} \cdot \mathrm{kg}^{-1}( \pm 30 \%)$

\subsection{Validation of the method}

\subsubsection{Repeatability of the analyses on soil samples by the SPME/GC-MS method}

The consistency of the chlordecone analyses was evaluated with ten replicates on different soils (table III): one reference mixture of soils used to control the performances of the equipment in our laboratory periodically, four andosols and four ferralsols with different levels of contamination. First, the data were very close whatever the method of quantitation used. Second, the variability of data obtained with the SPME/GC-MS method increased when the level of contamination decreased clearly for the ferralsols (12.0\% to $28.0 \%$ ), and ranged from $6.8 \%$ to $25.2 \%$ for andosols. The difference may be a result of the organic carbon and allophane content being highly variable in andosols. Nevertheless, the data are similar to the variability claimed by the LDA26 $( \pm 30 \%)$. They included the whole process of sampling, sub-sampling, the SPME extraction and the analysis by GC-MS.

\subsubsection{Comparison of soil analyses using the proposed method and the normalised method}

The analysis data were compared on 70 duplicated andosol samples analysed and quantified by the CIRAD and LDA26 laboratories. The correlation coefficient between the two sets of data (figure 6 ) was $r=0.86$, which is very good if we take into account that these data represent trace analyses and that the accuracy of the chlordecone analyses is about 30\%. Another point is the fact that the analyses were done in two different laboratories, and it is well known that in these conditions, results sometimes vary considerably. 
Figure 6.

Comparison of soil chlordecone contamination estimates by SPME (CIRAD) or hot solvent extraction [Laboratoire Départemental d'Analyses (LDA26)] and GC-MS techniques. Seventy samples were analysed in duplicate both in the CIRAD laboratory by the SPME/GCMS method and the LDA26 by the normalised method. For the SPME/GC-MS method: quantitation by three standard additions and zero-intercept calculation.

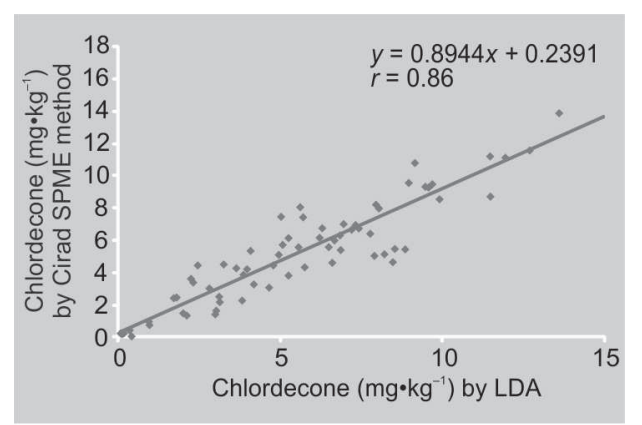

3.5.3. Comparison of soil analyses using the proposed method and a SPME method with chlordecone $\mathrm{C}_{13}$ as an internal standard

Two sets of data were obtained from the duplicated soil samples [contamination ranging from (0.2 to 9.7) $\mathrm{mg} \cdot \mathrm{kg}^{-1}$ ] using the two SPME/GC-MS techniques and the associated modes of calculation described above: the first one with Metox as an internal standard and calculation based on standard additions with the zero intercept in the CIRAD Martinique laboratory, and the second one with chlordecone- $\mathrm{C}_{13}$ as an internal standard in the CIRAD Montpellier (France) laboratory.

The good correlation ( $r=0.8073$ ) shows that the results obtained with the two methods were close and that both can be used for chlordecone trace analyses in environmental samples. This also confirms that the use of Metox as an internal standard was appropriate in our case. Nevertheless, except for its cost, chlordecone ${ }_{13}$ is probably a more interesting internal standard. A direct measurement of the [chlordecone/ chlordecone $_{13}$ ] ratios can be compared with a calibration curve in water whatever the matrix.

It is interesting to note that neither method required exhaustive chlordecone extraction of the matrix for quantitation. Consequently, knowing the percentage of recovery was not important with these methods.

\subsection{Quantitation of soil contamination by SPME/GC-MS/MS}

The SPME/GC-MS/MS method was applied to an andosol at three different levels of chlordecone contamination: $(1.0,3.0$ and 6.0) $\mu \mathrm{g} \cdot \mathrm{kg}^{-1} \mathrm{dw}$, obtained by dilution with a non-contaminated andosol. The results showed a good linear relationship between the chlordecone uptake and the contamination with $R^{2}=0.9933$. The [signal:noise] ratios were 262, 706 and 1511 for, respectively, (1, 3 and 6) $\mu \mathrm{g} \cdot \mathrm{kg}^{-1} \mathrm{dw}$, still far above the limit of quantitation (LOQ) given above $\left(80 \mathrm{ng} \cdot \mathrm{kg}^{-1} \mathrm{dw}\right)$. The last dilution $\left(6 \mu \mathrm{g} \cdot \mathrm{kg}^{-1}\right.$ $\mathrm{dw}$ ) was used for LOQ determination in MS/ MS.

The MS/MS method can be used in routine analyses of chlordecone contamination because it is not restricted to low levels of contamination, but also when interferences with other molecules in a complex matrix may be in competition for the binding sites on the fibre. Nevertheless, it has been demonstrated that mixing several pesticides even at relatively high concentrations in water does not affect the linearity of the uptake of one specific pesticide [39]. This is probably true until all the binding sites are occupied by molecules, which may occur if the fibre is soaked in the water for a very long time or if the matrix has a very complex structure. The short soaking time we used (10 min) reduced the risk of interferences. Finally, when this option is available on the MS detector, the MS/MS method is also a good alternative for trace analyses of chlordecone.

\section{Conclusion}

The data presented here confirm that a quantitative analysis with a short time release of chlordecone from the matrix sample into the water is possible with a SPME technique if an appropriate calculation method is used (standard addition with the zero intercept). The data were very close to those obtained by the LDA26 with hot solvent extraction, and with another SPME method using chlordecone- $\mathrm{C}_{13}$ as an internal standard, for water plant and soil samples. Limits of detection and quantitation were similar to those of the literature using the same type of technology (GC-MS or GCMS/MS). 
The proposed method greatly simplifies the protocol for the analysis of chlordecone in water, plant and soil samples. First, the sampling and sub-sampling procedures do not require complete drying of large samples. Only a few milligrams of sample need to be dried for calculations of dry weight. Second, the 10-min SPME procedure just before injection into the GC is short and does not require solvent extraction or additional cleaning of the extracts as used, for example, on Florisil ${ }^{\circledR}$ columns to eliminate some of the contamination due to the many compounds extracted by the hot solvent. Third, the standard addition procedure with calculation of the zero intercept requires four analyses per sample, which represent both the replicates and 'the standard curve' of the analysis with no need for further analyses to determine the percentage of recovery of each sample.

Further improvement may be needed for the SPME extraction of chlordecone from animal samples because of the lipophilic character of this pesticide.

The contamination of soils by chlordecone in the French West Indies is expected to last for centuries due to the slow release of chlordecone in running and underground water, which, in turn, causes continuous contamination of plants and crops, livestock and sea biota. One can assume that the environmental problems caused by chlordecone will not be limited to the FWI but will affect many African and European countries, even if they have not yet come to light. This method, which is reasonably easy to better implement, will be a great help in studies to understand and control pollution of the environment by chlordecone.

\section{References}

[1] Cabidoche Y.M., Achard R., Cattan P., Clermont-Dauphin C., Massat F., Sansoulet J., Long-term pollution by chlordecone of tropical volcanic soils in the French West Indies: A simple leaching model accounts for current residue, Environ. Pollut. 157 (2009) 1697-1705.
[2] Ramdine G., Lemoine S., Anthropogenic contaminations in the mangrove of Guadeloupe (Lesser Antilles): use of a biomarker of genotoxicity for monitoring, in: Proc. 61st Gulf Carrib. Fish. Inst., Nov. 10-14, Gosier, Guadeloupe, F.W.I., 2008.

[3] Multigner L., Ndong, Giusti A., Romana M., Delacroix-Maillard H., Cordier S., Jégou B., Thome J.P., Blanchet P., Chlordecone exposure and risk of prostate cancer, J. Clin. Oncol. 28 (2010) 3457-3462.

[4] Multigner L., Kadhel P., Huk-Terki F., Thomé J.P., Janky E., Auger J., Exposure to chlordecone and male fertility in Guadeloupe (French West Indies), Epidemiology 17 (2006).

[5] Multigner L., Cordier S., Kadhel P., Huc-Terki F., Blanchet P., Bataille H., Pollution par le chlordécone aux Antilles, quel impact sur la santé de la population?, Environ. Risques Santé 6 (2007) 1-3.

[6] Epstein S.S., Kepone - Hazard evaluation, Sci. Total Environ. 9 (1978) 1-62.

[7] Okolle J.N., Fansi G.H., Lombi F.M., Lang P.S., Loubana P.M., Banana entomological research in Cameroon: how far and what next?, Afr. J. Plant Sci. Biotechnol. 3 (2009) 1-19.

[8] Kilzer L., Scheunert I., Geyer H., Klein W., Korte F., Laboratory screening of the volatization rates of organic chemicals from water and soil, Chemosphere 10 (1979) 751-761.

[9] Wada K., The distinctive properties of andosol, in: Stewart B.A. (Ed.), Advances in soil sciences, Springer Verlag, N.Y., U.S.A., 1985.

[10] ChevallierT., WoignierT., ToucetJ., Blanchart E., Dieudonné P., Fractal structure in natural gels: effect on carbon sequestration in volcanic soils, J. Sol-Gel Sci. Technol. 48 (2008) 231-238.

[11] Woignier T., Morell M., Morell O., Duffours L., Soler A., Low water transport in fractal microstructure of tropical soils: application to chlordecone pesticide trapping, Ecohydrol. Hydrobiol. 11 (2011) 121-128.

[12] Woignier T., Fernandes P., Jannoyer-Lesueur M., Soler A., Sequestration of chlordecone in the porous structure of an andosol and effects of added organic matter: an alternative to decontamination, Eur. J. Soil Sci. 63 (2012) 717-723.

[13] WoignierT., Fernandes P., Soler A., Clostre F., Carles C., Rangon L., Lesueur-Jannoyer M., Soil microstructure and organic matter: keys 
for chlordecone sequestration, J. Hazard Mater. 262 (2013) 357-364.

[14] Cabidoche Y.M., Lesueur-Jannoyer M., Contamination of harvested organs in root crops grown on chlordecone-polluted soils, Pedosphere 22 (2012) 562-571.

[15] Saleh F.Y., Lee G.F., Analytical methodology for Kepone in water and sediment, Environ. Sci. Technol. 12 (1978) 297-301.

[16] Bordet F., Thieffinne A., Mallet J., Heraud F., Blateau A., Inthavong D., In-house validation for analytical methods and quality control for risk evaluation of chlordecone in food, Int. J. Environ. Anal. Chem. 87 (2007) 985-998.

[17] Cairns T., Siegmund E.G., Doose G.M., Liquid chromatography/mass spectrometry of Kepone hydrate, Kelevan, and Mirex, Anal. Chem. 54 (1982) 953-957.

[18] Moseman R.F., Crist H.L., Edgerton T.R., Ward M.K., Electron capture gas chromatographic determination of Kepone residues in environmental samples, Arch. Environ. Contamin. Toxicol. 6 (1977) 221-231.

[19] Bristeau S., Amalric L., Mouvet C., Validation of chlordecone analysis for native and remediated French West Indies soils with high organic matter content, Anal. Bioanal. Chem. 406 (2014) 1073-1080.

[20] Martin-Laurent F., Sahnoun M.M., Merlin C., Vollmer G., Lubke M., Detection and quantification of chlordecone in contaminated soils from the French West Indies by GC-MS using the (13)C 10-chlordecone stable isotope as a tracer, Environ. Sci. Pollut. Res. Int. (2013) 1-6.

[21] Amalric L., Henry B., Berrehouc A., Determination of chlordecone in soils by GC/MS, Int J. Environ. Anal. Chem. 86 (2006) 15-24.

[22] Anon., Effet des matériaux sur la qualité des eaux destinées à la consommation humaine - Matériaux organiques, Part. 2 : méthode de mesure des micropolluants minéraux et organiques, Norme AFNOR XP P41-250-2, AFNOR, Paris, France, 2001

[23] Harris R.L., Huggett R.J., Slone H.D., Determination of dissolved Kepone by direct addition of XAD-2 resin to water, Anal. Chem. 52 (1980) 779-780.

[24] Brunet D., Woignier T., Lesueur-Jannoyer M., Achard R., Rangon L., Barthès B.G., Determination of soil content in chlordecone (organochlorine pesticide) using near infrared reflectance spectroscopy (NIRS), Environ. Pollut. 157 (2009) 3120-3125.
[25] Hawthorne S.B., Grabanski C.B., Miller D.J., Solid-phase-microextraction measurement of 62 polychlorinated biphenyl congeners in milliliter sediment pore water samples and determination of KDOC values, Anal. Chem. 81 (2009) 6936-6943.

[26] Beltran J., López F.J., Hernández F., Solidphase microextraction in pesticide residue analysis, J. Chromatogr. A 885 (2000) 389404.

[27] Ai J., Solid phase microextraction for quantitative analysis in nonequilibrium situations, Anal. Chem. 69 (1997) 1230-1236.

[28] Wan H.B., Wong M.K., Minimization of solvent consumption in pesticide residue analysis, J. Chromatogr. A 754 (1996) 43-47.

[29] Beltran J., Lopez F.J., Cepria O., Hernandez F., Solid-phase microextraction for quantitative analysis of organophosphorus pesticides in environmental water samples, J. Chromatogr. A 808 (1998) 257-263.

[30] Eisert R., Levsen K., Determination of pesticides in aqueous samples by solid-phase microextraction in-line coupled to gas chromatography--mass spectrometry, J. Am. Soc. Mass Spectrom. 6 (1995) 1119-1130.

[31] Gonçalves C., Alpendurada M.F., Solidphase micro-extraction-gas chromatography-(tandem) mass spectrometry as a tool for pesticide residue analysis in water samples at high sensitivity and selectivity with confirmation capabilities, J. Chromatogr. A 1026 (2004) 239-250.

[32] Vázquez P.P., Mughari A.R., Galera M.M., Solid-phase microextraction (SPME) for the determination of pyrethroids in cucumber and watermelon using liquid chromatography combined with post-column photochemically induced fluorimetry derivatization and fluorescence detection, Anal. Chim. Acta 607 (2008) 74-82.

[33] Guillot S., Kelly M.T., Fenet H., Larroque M., Evaluation of solid-phase microextraction as an alternative to the official method for the analysis of organic micro-pollutants in drinking water, J. Chromatogr. A 1101 (2006) 4652.

[34] Fidalgo-Used N., Centineo G., BlancoGonzález E., Sanz-Medel A., Solid-phase microextraction as a clean-up and preconcentration procedure for organochlorine pesticides determination in fish tissue by gas chromatography with electron capture detection, J. Chromatogr. A 1017 (2003) 35-44. 
[35] Ostroukhova O., Zenkevich I., A comparison of the external standard and standard addition methods for the quantitative chromatographic determination of pesticide concentrations in plant samples, J. Anal. Chem. 61 (2006) 442-451.

[36] Zenkevich I., Klimova I., Use of the standard addition method in quantitative chromatographic analysis, J. Anal. Chem. 61 (2006) 967-972.

[37] Bristeau S., Ghestem J.P., Résultats de l'essai interlaboratoires chlordécone et chlordécone-5b-hydro dans les eaux de surface continentales et eaux souterraines, BGRM, Rapp. Final, Rapp. AQUAREF- RP-61916FR, BRGM, France, 2012.

[38] Woignier T., Clostre F., Macarie H., Jannoyer M., Chlordecone retention in the fractal structure of volcanic clay, J. Hazard Mater. 241-242 (2012) 224-230.

[39] Dugay J., Miège C., Hennion M.C., Effect of the various parameters governing solidphase microextraction for the trace-determination of pesticides in water, J. Chromatogr. A 795 (1998) 27-42.

\section{Microextracción en fase sólida y cromatografía de gases-espectrometría de masas para la determinación cuantitativa de la clordecona en muestras de agua, plantas y suelo.}

Resumen - Introducción. La clordecona (CLD), organoclorado anteriormente utilizado para controlar el picudo negro del banano, se adsorbe fuertemente en suelos, como andosol. Un procedimiento simplificado para cuantificar residuos de CLD en agua, micro-muestras de suelo y de plantas fue comparado a un método estándar. Materiales y métodos. El procedimiento combina un muestreo simplificado y una micro-extracción en fase sólida (SPME) durante $10 \mathrm{~min}$, separación por cromatografía en fase gaseosa (GC) e identificación por espectrometría de masas (MS y MS/ MS). La cuantificación se realizó mediante un método de adición estándar. Se analizaron setenta muestras con el método propuesto y un método estándar (extracción con solvente caliente). Quince muestras de suelo fueron analizadas por dos métodos SPME / GC-MS, una con la CLD C 13 como estándar interno y la otra el método propuesto. Resultados y discusión. Los límites de detección (LOD) y de cuantificación ( LOQ ) con la extracción de SPME de 10 min se han determinado en GC-MS y GC-MS/MS en muestras de agua, de plantas (raíces de piña) y de suelo : en agua, con la MS/MS, LOD $\mathrm{MS} / \mathrm{MS}$, LOD $\mathrm{MS}_{\mathrm{MS}-\mathrm{suelo}}=15,0 \mathrm{ng} \cdot \mathrm{kg}^{-1} \mathrm{~ms}$ y LOQ $\mathrm{LO}_{\mathrm{MS}} \mathrm{MS}$-suelo $=80,0 \mathrm{ng} \cdot \mathrm{kg}^{-1} \mathrm{~ms}$. Los datos de contaminación sobre los 70 suelos obtenidos con el método propuesto y con el método estándar mostraron un coeficiente de correlación $r=0,86$. Los datos obtenidos con los dos procedimientos de cuantificación con SPME / GC-MS mostraron una correlación $r=0,8073$. Conclusión. El método proporciona una preparación rápida de muestras y una extracción de CLD simplificada en agua, plantas y suelo, sin manipulación de solventes. Los límites de detección y de cuantificación fueron similares a los métodos usuales. El método fiable y preciso, sería útil a fines de investigación.

Francia (Martinica) / clordecona / extracción / técnicas analíticas / análisis cuantitativo/ análisis de agua / análisis del suelo / análisis de tejidos 